\title{
Occlusal Guidance and Occlusal Planes at Different Ages and Different Occlusion Groups Follow the Sequential Occlusion Concept
}

\author{
Junji Takei, Susumu Akimoto, Sadao Sato
}

\begin{abstract}
Tooth guidance was studied in 5,146 Japanese subjects, aged 10 to over 60 years, with complete dentitions. Casts mounted on an SAM articulator with face bow-transfer offered the possibility to measure the guidance inclination on both sides of the dentitions. The functional points F1 and F2, which represent the starting point and end point of the tooth guidance, were recorded by a 3Ddigitizer on maxillary teeth from central incisor to second molar. The inclination of the line connecting F1 to F2 with reference to the axis orbital plane was calculated for each tooth. The inclination of the occlusal plane connecting the F1 points of all teeth from central incisor to first molar, central incisor to first premolar, and second premolar to second molar was also calculated. The values were compared in different age groups and different occlusion groups; Angle Class I, II , and III relationships. The average occlusal guidance sequentially decreased from anterior to posterior. Occlusal guidance indicated that inclinations of canine and first premolar gradually decreased with age, while those of molars were increased. The occlusal plane measurements showed that although the anterior occlusal plane was relatively stable with age, the posterior occlusal plane continuously and gradually flattened. The results confirmed the concept of sequential guidance with canine dominance, although the inclinations of guidance between neighboring teeth decreased with age.
\end{abstract}

完全な歯列を持つ 10 代から 60 歳代までの日本人 5,146 人の咬合誘導路について研究し た.フェイスボウにて SAM 咬合器に装着された研究模型の左右両側の機能上の誘導路角 を3Dデジタイザーを用いて計測した。異なる臼歯咬合関係や年齢を評価した。アングル I 級, II 級, III 級の臼歯部咬合関係と咬合誘導路および咬合平面との関係について比較検 討した。 その結果, 犬歯第一小臼歯の咬合誘導路の傾斜は, 加齢にともなって徐々に減少 する傾向を示し，後方歯の咬合誘導路の傾斜は徐々に増加した．後方部咬合平面（pOP） は，加齢にともなって徐々に平坦化した。この変化は相対顆路傾斜角を増加させ，臼歯離 開をより容易にする変化であった。また，アングル I 級における pOP はアングル I 級およ びIII級と比べ急峻となっており, 後方歯において干渉を生じる危険性が増大することが示 
唆された。これらの結果から加齢による咬合誘導のパターンの変化としては犬歯誘導からグ ループファンクションの傾向になるものの，生涯を通して犬歯主導順次誘導咬合を維持する ものと考えられた。

Key words : 犬歯主導型順次誘導咬合 sequential guidance with canine dominance, 咬合誘 導路 guidance inclinations, 咬合平面 occlusal plane

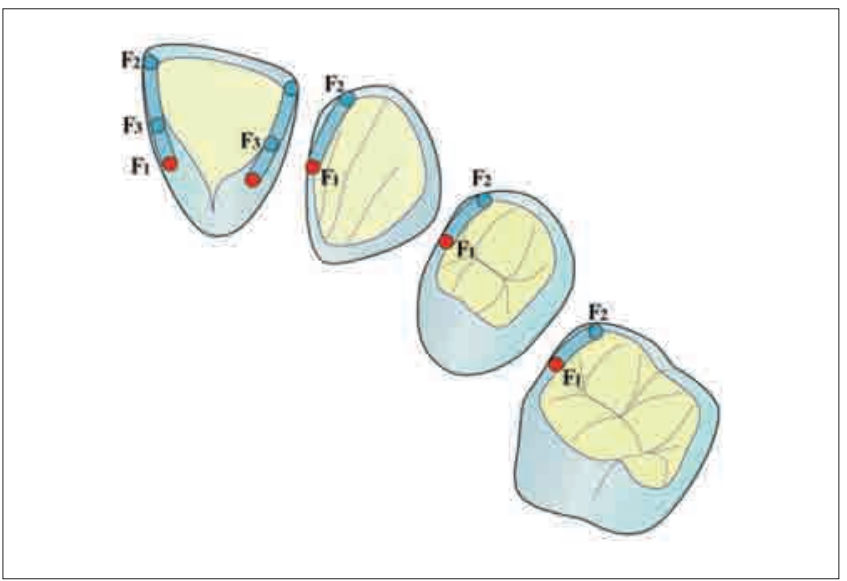

図 1 咬合誘導路の計測点. 上顎の切歯, 犬歯, 小臼歯および大臼 歯の近心辺緑隆線上で下顎の㚘側咬頭頂が咬頭嵌合で接触する点を 咬合誘導路の機能的出発点 F 1 とし, 偏心運動で上下顎歯が離開する 直前の外側機能点をF2とした. さらに上顎前歯舌側凹面の機能的最 深点をF3とした

\section{はじめに}

歯科医学は咬合の構築あるいは再構成を目的とする医療 体系である。今日, 科学的根拠に基づいた歯科医療 (evidence based dentistry) が求められている一方, 日常臨 床における咬合構築は歯科医師と歯科技工士の経験と勘に 頼る experience-based reconstruction となっているのが現状 である、咬合構築を科学的根拠に基づたものとするため には, それぞれの患者のもっている条件, すなわち顎顔面 骨格形態や顎関節の形態と機能をはじめとして顆路角, 咬 合平面，歯列および歯の形態などを個別化して把握する必 要がある。その上で個々の咬合治療計画を立案することに なるが，その際に必要となるのが咬合の基本的な原理原則 に則った咬合構築の標準化である。したがって, それを達 成するためには，咬合構築に関わる科学的根拠を蓄積する 必要がある。

天然歯の咬合面形態は，基本的には後方の歯から順次的
に離開するような咬合誘導路の傾斜が備わっているとされ ているが1-3)，日本人における咬合様式に関しては佐藤 ら ${ }^{4-6)}$ の報告があるのみで，なお明確な説明はなされてい ない.とくに骨格形態には多様性があり, 骨格や咬合パター ンと咬合誘導路，咬合平面の関係などについて不明な点が 多い.

本研究は，これらの点を明確にする目的で，とくに，ア ングル I 級， II 級， III 級の臼歯部咬合関係と咬合誘導路お よび咬合平面との関係について比較検討した。

\section{資料と方法}

本研究では日本人の歯の形態，とくに田歯部咬合関係と 咬合誘導路および咬合平面について調査検討した。用いた 資料において第三大臼歯, 補経処置歯, および位置異常歯 は評価対象から除外した。

上顎模型はAxis-Or plane（AOP） を基準として解剖学的 フェイスボウ（SAM, Prazisionstechnik, Munichen, Germany） を用いてSAM 2 咬合器 (SAM, Prazisionstechnik, Munichen, Germany）に付着された。下顎模型の付着にはチンポイン ト法による咬合採得記録を用いた。

本研究で用いた資料の内訳は，臼歯部咬合関係で分類す ると両側性アングル I 級が 1,571 例, 両側あるいは片側ア ングル II 級が 1,087 例, 両側あるいは片側アングル III 級が 1,277例であった。

咬合誘導路は，下顎の前方および側方運動を対象として 計測した。咬合誘導路の機能的出発点（F1）と終点（F2） は, 上顎の切歯と犬歯, 小臼歯と第一大臼歯の近心の辺縁 隆線に図 1 に示すように設定した。 さらに，上顎前歯舌側 の機能的最深点を F3とした。これら FlとF2を結んだ誘導 路とAOPのなす角度および距離について3Dデジタイザ (Gamma Co. Ltd, Klosterneuburg, Austria) を用いて計測し た (図2).

咬合平面は，AOP に対してF1を結んだ3つの異なる平 面を計測した。従来の標準的咬合平面 (cOP) は中切歯 F1 


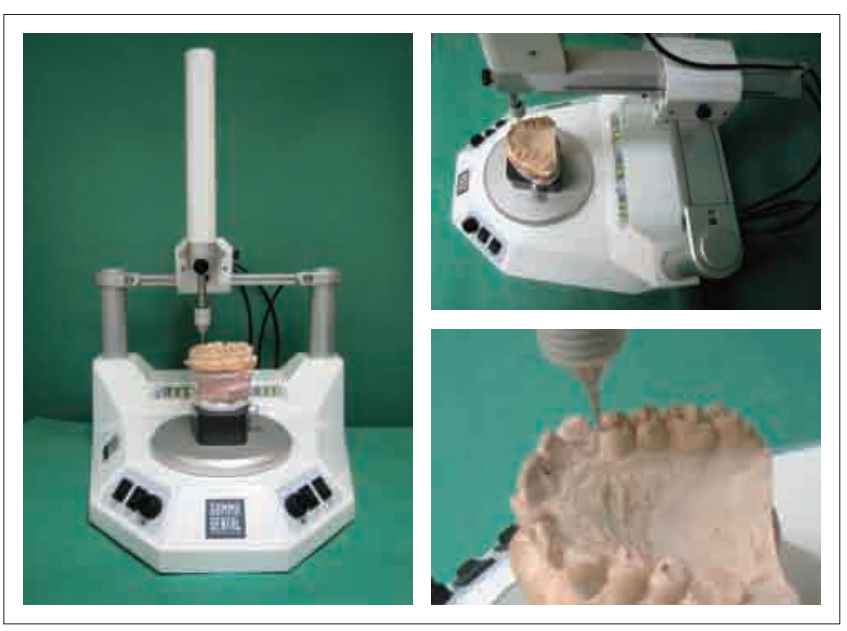

図2 機能点の計測. 咬合誘導路の機能的出発点 (F1) と終点 (F2) を結んだ誘導路とAOP との角度および 2 点間の距離について 3D デ ジタイザーを用いて計測した.

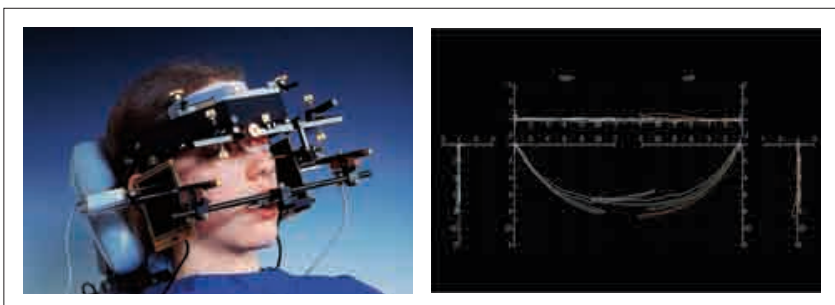

図4 矢状顆路傾斜角 (SCI) の計測. 矢状顆路傾斜角 $(\mathrm{SCl})$ は サンプル・グループの中から下顎運動時の運動制限や変曲点などの 問題の認められない 142 名の被験者のコンダイログラフィー (Condylography, Cadiax) のデータを用い, 前進運動, 左右側方 運動時の前方 $3 \mathrm{~mm}, 5 \mathrm{~mm}$ および $10 \mathrm{~mm}$ の点について計測した.

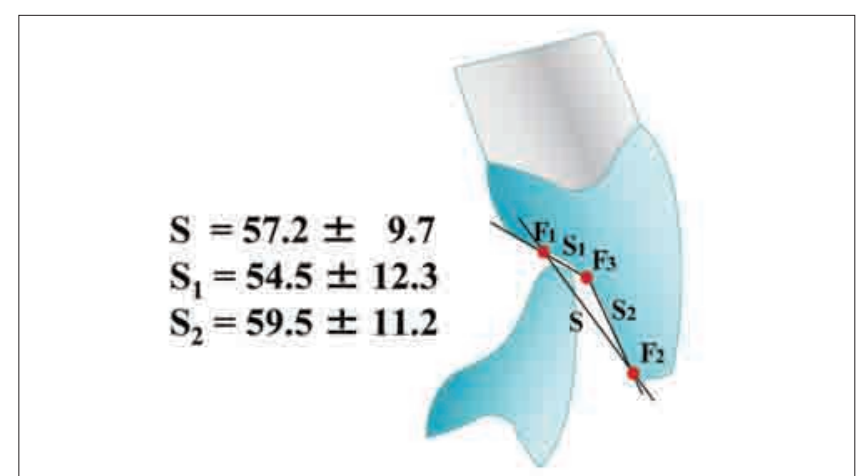

図6 上顎前歯舌側の咬合誘導路角. 上顎前歯舌側の咬合誘導路角 S (F1-F2) は 57.2 度であった. さらに舌側機能的最深点F3を含 む2つの平面, すなわち平坦な傾斜 S I (F1-F3) 部分と急な傾斜 S2（F3-F2） 部分とに分けて計測した結果, それぞれ 54.5 度と 59.5 度であった.

と第一大臼歯 $\mathrm{F} 1$ を結んだ平面とし, 中切歯F1 と第一小臼 歯F1 を結ぶ平面を前方咬合平面 ( $\mathrm{aOP})$ ，第二小臼歯 $\mathrm{F} 1$ と 第二大臼歯 F1 を結ぶ平面を後方咬合平面（pOP）とした (図 3).

矢状顆路傾斜角 $(\mathrm{SCI})$ はサンプル・グループの中から下 顎運動時の運動制限や変曲点などの問題の認められない

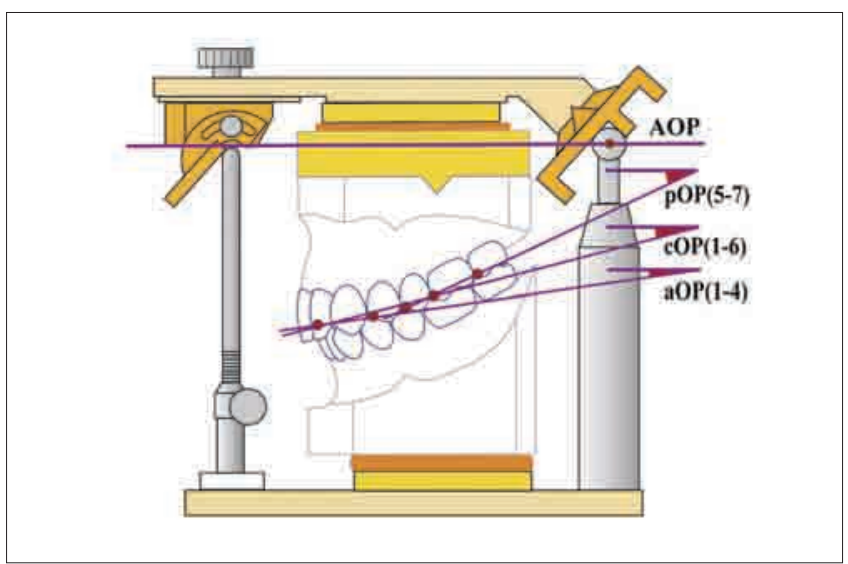

図3 咬合平面の計測. 咬合平面は, $\mathrm{F} 1$ を結んだろつの異なる平面 をAOPに対する角度として計測した，標準的咬合平面 (cOP) は中 切歯 $F 1$ と第一大臼歯 $F 1$ を結んだ平面とし, 中切歯 $F 1$ と第一小臼 歯 $\mathrm{F} 1$ を結ぶ平面を前方咬合平面 (aOP), 第二小臼歯 $\mathrm{F} 1$ と第二大 臼歯F1 を結ぶ平面を後方咬合平面 (pOP) とした.

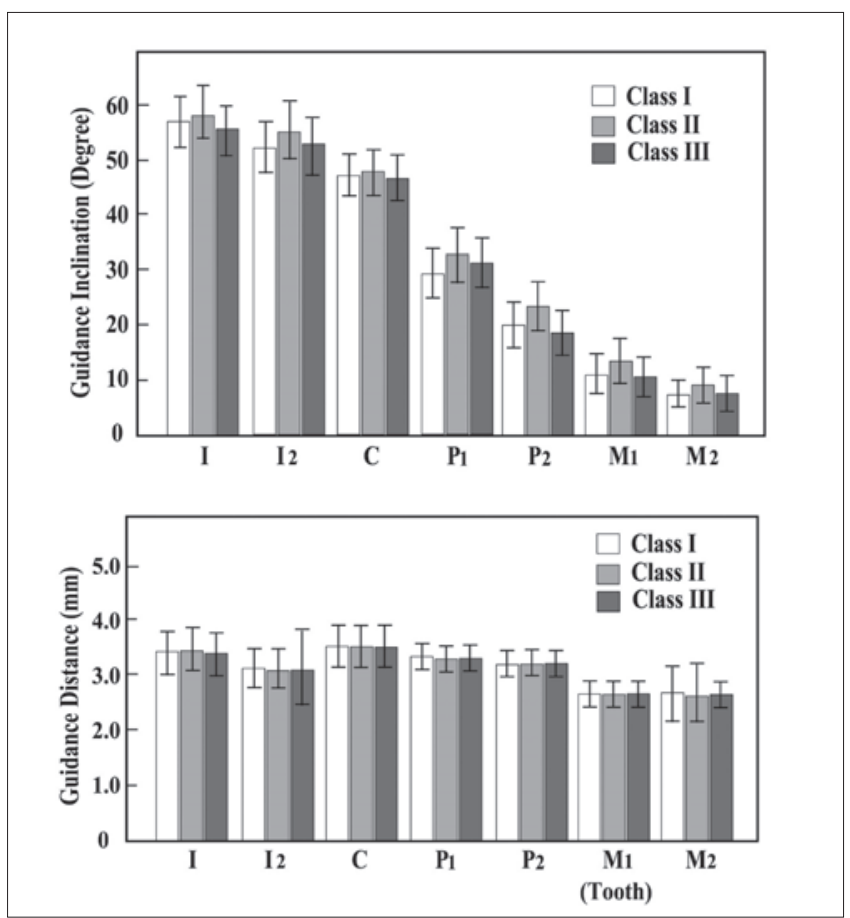

図 5 咬合誘導路の角度および距離。上顎歯の平均的咬合誘導路角 (F1-F2) は, 第二大臼歯の8.7 度から中切歯の57.2 度になってお り, 後方から前方に向かって誘導路角が順次的に急傾斜となってい た. 切歯を除いてもっとも急な誘導路は犬歯で見られ, その咬合誘 導路は 47 度であった。 咬合誘導路 (F1-F2) の平均距離は, 大臼 歯の2.7mmから犬歯の3.6mmになっていた。

142 名の被験者の condylography ${ }^{7)}$ (Cadiax, Gamma Co. Ltd, Klosterneuburg, Austria）を用いて記録した下顎頭運動パター ンを用いて計測した.SCIは下顎頭の滑走運動である前進 運動, 左右側方運動時の前方 $3 \mathrm{~mm}, 5 \mathrm{~mm}$ および $10 \mathrm{~mm}$ の点 について計測した（図4）. 


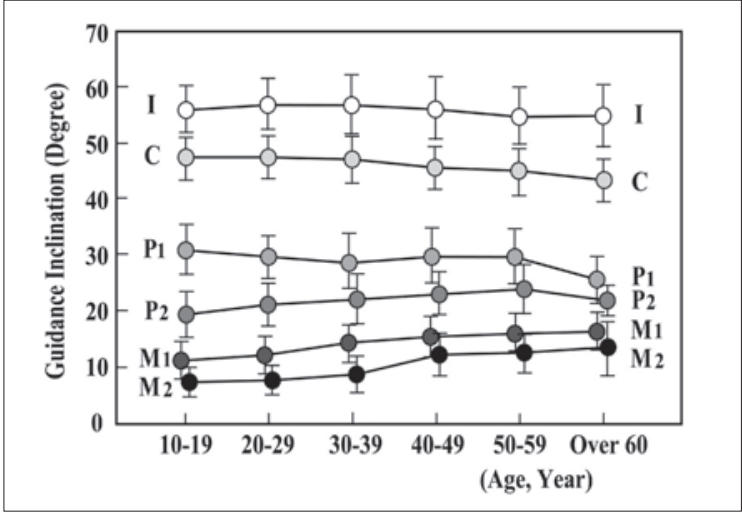

図7 年齢と咬合誘導路. 加齢にともなう咬合誘導路角の変 化としては，犬歯の咬合誘導路の傾斜が 47.7 度か 542.5 度に，第一小臼歯の咬合誘導路も 31.8 度から25.8 度に 徐々に減少していた. 第二小臼歯の誘導傾斜は, 年齢にかか わりなくおよそ20度で維持された．しかし，第一大臼歯と 第二大臼歯の咬合誘導路角は, 加齢にともなって徐々に増加 した.

\section{結果}

\section{I．咬合誘導路の傾斜角}

日本人天然歯列の咬合誘導路はアングル I 級，II 級およ び級のいずれにおいても，中切歯がもっとも急峻な角度 を示し，前歯から後方歯にいくに従って順次的に減少して いた（図5).

アングル I 級と II 級の咬合誘導路角の比較では，犬歯に のみ有意差が認められなかったが他のすべての歯種におい てアングル II 級が有意に急峻であった。アングル I 級と III 級の比較においては, 中切歯, 側切歯, 第一小罒歯および 第一大臼歯において I 級が急傾斜となっていた。アングル II 級と II 級の関係ではすべての歯種において I 級が有意に 急傾斜となっており，I 級がその中間の誘導路角を示した。

歯種間における誘導路の角度差は犬歯と第一小臼歯との 間が 17 度と一番大きな值を示した。他の歯種間における 差は 10 度以下となっていたが，いずれの臼歯関係におい ても後方から前方に向かって歯の誘導路角が急傾斜となる 順次誘導咬合の概念と一致していた。一方，誘導距離につ いてはアングル I 級，II 級，III級における差は認められな かった

\section{II．上顎前歯の咬合誘導路角（図 6)}

上顎前歯舌側の誘導路角 S（F1-F2）は57.2度であった。 更に舌側面機能的最深点F3 含む $2 つ$ 平面，すなわち平 坦な傾斜 $\mathrm{S} 1$ （F1-F3）部分と急な傾斜 S2（F3-F2）部分と に分けて計測した結果，それぞれ54.5度と 59.5 度であった。

\section{III. 加齢にともなう咬合誘導路角の変化（図7}

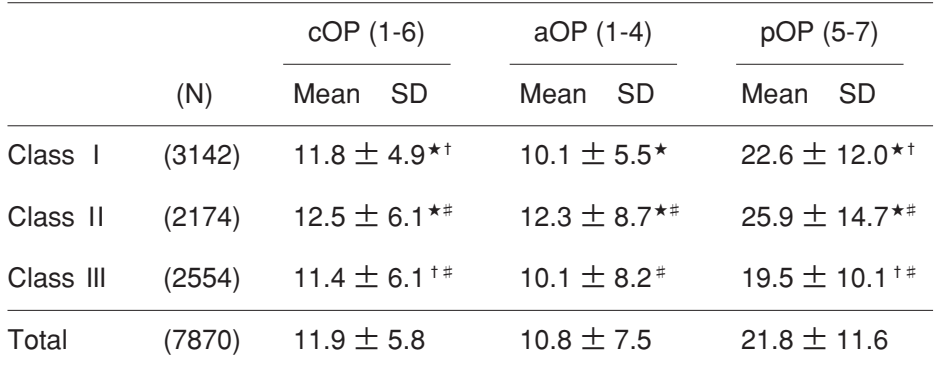

^Significantly different between Class I and Class II, at $\mathrm{P}<0.05$

${ }^{\dagger}$ Significantly different between Class I and Class III, at $P<0.05$

"Significantly different between Class II and Class III, at $\mathrm{P}<0.05$

表 1 臼歯部咬合関係と咬合平面傾斜角

咬合誘導路の加齢にともなう変化としては，犬歯の咬合 誘導路の傾斜が 47.7 度から 42.5 度に，第一小臼歯の咬合誘 導路も 31.8 度から 25.8 度に徐々に減少することが証明され た。第二小臼歯の誘導傾斜は，年齢にかかわりなく拉よそ 20 度で維持された。しかし，第一大臼歯と第二大臼歯の咬 合誘導路角は，加齢にともなって徐々に増加した。これら の変化から隣接歯間の角度差が加齢にともなって減少する 結果となり，グループファンクションへ移行する傾向にあ ることが示唆された。天然歯のすべてのデータから 60 歳 代の年齢層においても咬合誘導路の傾斜は前歯から大白歯 にかけて徐々に減少していることが分かった。

\section{N． 臼歯部咬合関係と咬合平面傾斜角（表 1)}

異なる臼歯部咬合関係における $\mathrm{cOP}$ の角度は，アングル I 級は 11.8 度，アングル II 級では 12.5 度と急峻な角度，ア ングル級では11.4度であった。aOPにおいてはアングル II 級で 12.3 度とわずかに急傾斜となっていた。一方，pOP ではアングル II 級は 25.9 度と急峻になっており，緩傾斜な アングル III 級の 19.5 度とは6度の差が認められた。

\section{V．咬合平面と加齢（図 8)}

加齢にともなう咬合平面傾斜角は，cOP は 10.2 度から 12.5 度, $\mathrm{aOP}$ は9.2度から 12.0 度と小さな範囲内での変化で あった。しかし，pOPは33.6度から17.2 度へと加齢にとも なって大きく平坦化した。

\section{V. 臼歯部咬合関係と矢状顆路傾斜角（SCI）（表2）}

異なる臼歯部咬合関係における前方運動時 $(5 \mathrm{~mm})$ の SCIはアングル I 級 50.2 度，II 級は 50.3 度，四級では 48.2 


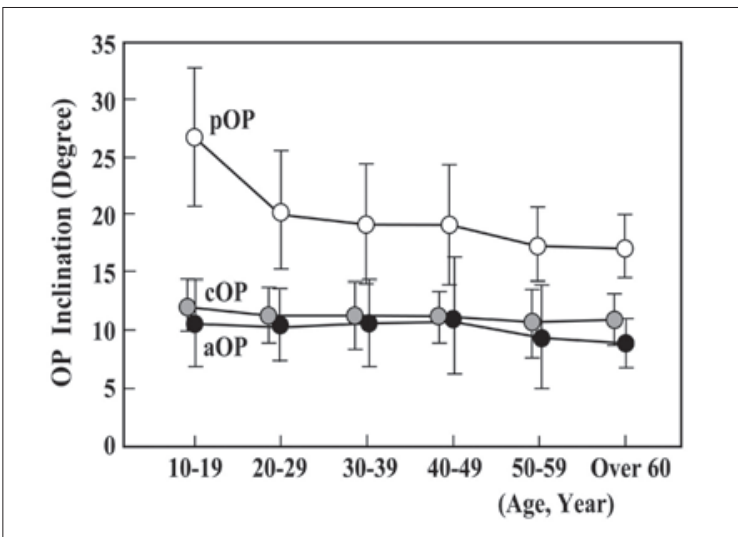

図8 年齢と咬合平面. 加齢にともなう標準的咬合平面の角 度は, およそ 11 度に維持された。前方咬合平面も, 9-12 度の範囲を維持し, 加齢による大きな変化は認められなかっ た.しかし, 後方咬合平面は 33.6 度から 17.2 度へと 15 度平坦化した。

\begin{tabular}{|c|c|c|c|c|}
\hline & Class I $(n=87)$ & Class II $(\mathrm{n}=70)$ & Class III $(n=53)$ & Total $(n=210)$ \\
\hline & Mean SD & Mean SD & Mean SD & Mean SD \\
\hline \multicolumn{5}{|l|}{ Pro/Ret } \\
\hline $\mathrm{S}=3 \mathrm{~mm}$ & $51.4 \pm 7.1$ & $51.1 \pm 8.0$ & $49.0 \pm 5.8$ & $50.7 \pm 7.2$ \\
\hline $\mathrm{S}=5 \mathrm{~mm}$ & $50.2 \pm 6.8$ & $50.3 \pm 7.5$ & $48.2 \pm 5.3$ & $49.8 \pm 6.7$ \\
\hline $\mathrm{S}=10 \mathrm{~mm}$ & $43.3 \pm 7.4$ & $43.6 \pm 7.1$ & $41.3 \pm 5.4$ & $42.9 \pm 6.9$ \\
\hline \multicolumn{5}{|c|}{ Medio/Medio-Ret } \\
\hline $\mathrm{S}=3 \mathrm{~mm}$ & $51.1 \pm 7.5^{\dagger}$ & $51.6 \pm 8.9^{\#}$ & $47.8 \pm 7.0^{\dagger \#}$ & $50.3 \pm 7.9$ \\
\hline$S=5 \mathrm{~mm}$ & $50.1 \pm 6.9$ & $50.9 \pm 8.2^{\#}$ & $47.2 \pm 6.1^{\#}$ & $49.5 \pm 7.2$ \\
\hline $\mathrm{S}=10 \mathrm{~mm}$ & $43.1 \pm 7.1$ & $44.3 \pm 7.7^{\#}$ & $40.7 \pm 6.1^{\#}$ & $42.8 \pm 7.1$ \\
\hline
\end{tabular}

${ }^{\dagger}$ Significantly different between Class I and Class III, at $\mathrm{P}<0.05$ "Significantly different between Class II and Class III, at $\mathrm{P}<0.05$

表 2 臼歯部咬合関係と矢状顆路傾斜角 $(\mathrm{SCl})$
度であり，それぞれの間の有意差は認められなかった。側 方運動時 $(5 \mathrm{~mm})$ のSCIにおいてアングル II 級は 50.9 度, III 級では 47.2 度であり，アングル II 級が急傾斜となってい た. SCIの平均傾斜角は, 前方 $3 \mathrm{~mm}$ および $5 \mathrm{~mm}$ において 50 度であった。アングルIII級においては，I級およびI 級 と比較して緩傾斜となっていた。

\section{考察}

本研究の結果から, 咬合誘導路はアングル I 級, II 級お よび而級のいずれの咬合関係においても中切歯がもっとも 急峻な角度を示し，後方歯にいくに従って順次的に減少し ていた（図 5)。これは，日本人天然歯列においても Slavicek (1982) 1,2) Kulmer ら (1999） 3) が提唱している 順次誘導咬合の概念と一致していることが明らかになっ た. 異なる臼歯部咬合関係と咬合誘導路との関係において, 一般的にはアングル II 級は高口蓋で歯列弓は狭く側方ガイ ダンスは急傾斜の傾向があり，四級では口蓋は浅く歯列弓 は大きく広がって側方ガイダンスはその分緩傾斜とされて いる ${ }^{8,9)}$. 今回の結果においても, アングル II 級の咬合誘導 路はアングル I 級および而級に対して有意に急傾斜となっ ており，III級はI 級と比較してさらに緩傾斜であった（図 5).

機能的咬合は, 咬合平面の傾斜と密接な関係がある。本 研究の異なる臼歯部咬合関係における $\mathrm{cOP}$ 角度は，アン グル I 級の 11.8 度を境としてアングル II 級では 12.5 度と急 峻な角度を示し，アングル III級では11.4度と緩やかな傾向 であった（表１）。顎顔面骨格と咬合平面傾斜角との関係 はセファログラムを用いた顎骨格（Denture Frame）の研 究から ${ }^{10-13)}$ II 級骨格では I 級や III 級に対して咬合平面は 急峻な傾向があり，而級骨格では平坦な傾向とされており，
本研究結果はそれらを裏付けるものとなっている.

一方, pOPでは臼歯部咬合関係における咬合平面傾斜角 度の差は増加していた（表 1 ）。

とくに，アングル II 級における pOP は2 5.9 度と急峻で あった。これが相対顆路傾斜角（RCI）を減少させる結果， 臼歯部の機能運動時における離開角が小さくなり, アング ル II 級の後方歯において干渉を生じる危険性が増大するこ とが示唆された。

加齢にともなう $\mathrm{cOP}$ および $\mathrm{aOP}$ の大きな変化は認められ なかったが, pOPにおいては33.6度から17.2度と平坦化した (図8).この変化はRCIを増加させ, 下顎の前進運動と側方 運動における後方臼歯部での離開を容易にすることになる. したがって，たとえ犬歯の誘導路角が加齢にともなって減 少しても, pOP が漸次に平坦化することによって機能咬合 における臼歯離開を補償されることが示唆された。

上顎前歯の咬合誘導路角は, 下顎運動時の臼歯離開を可 能にするためにSCIより 5-10度急傾斜の必要があるとされ ている ${ }^{2,4,14)}$. 逆に 15 度以上急峻な場合には, 咀嚼効率を 低下させるばかりでなく顎機能にも問題を生じるとされて いる ${ }^{14)}$. 今回の上顎前歯誘導路角 57 度とSCI の 50 度とい う結果から導きだされた 7 度という角度差は, 臼歯離開を 可能とする標準值と考えられるものとなっている (図9).

犬歯の咬合誘導路角と SCI はそれぞれ 48 度と 50 度であ り，近似した值を示した（図 10)。下顎がブラキシズム のような強い機能圧で動くとき, 前方では, 咬合誘導路 (アンテリアガイダンス) に沿った運動を示し，後方は SCI（ポステリアガイダンス）の角度に従って誘導される ことになる。この前方誘導路と後方誘導路が平行な関係に なっていることは, 睡眠ブラキシズムのような強い食いし ばり時においてさえ，スムーズで低い筋肉エネルギーでの 


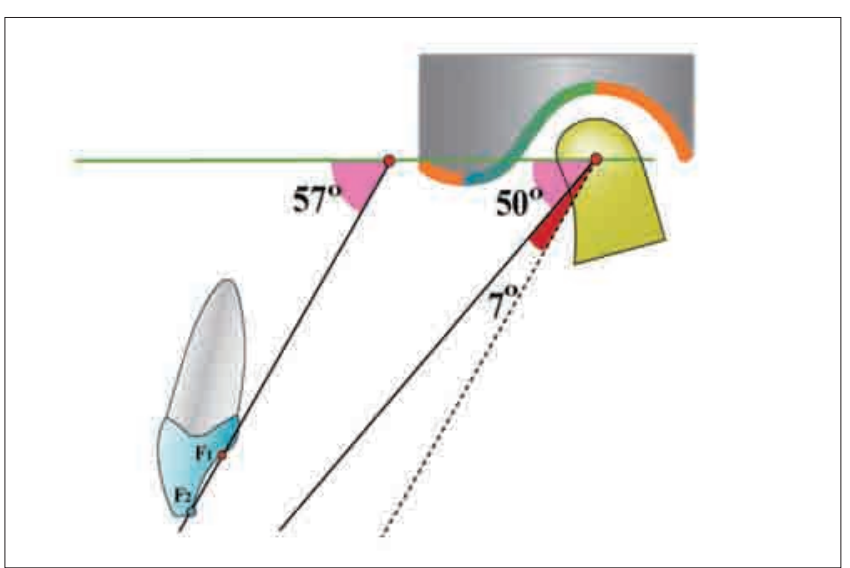

図 9 前方誘導路と矢状顆路傾斜角 (SCI). 上顎前歯の前方誘導路 は, 矢状顆路傾斜角より約 7 度急峻であった。

ブラキシズムを可能にしていることが示唆された。

\section{結論}

本研究の結果，アングル I 級， I 級および III級のいずれ の咬合関係においても前歯から臼歯に向かって咬合誘導路 角が順次性に減少する犬歯主導の順次誘導咬合の概念を確 認できた. 加齢にともなって犬歯第一小臼歯の咬合誘導路 は徐々に減少する傾向を示した。 それとは逆に後方歯の咬 合誘導路は徐々に増加した。これらの結果から加齢による 咬合誘導のパターンの変化としては犬歯誘導からグループ ファンクションの傾向になるものの, 生涯を通して犬歯主

\section{参考文献}

1) Slavicek, R. : Okklusionskonzeple. Inf. Orthod. Kieferorthop., 14 : 253-263, 1982.

2) Slavicek, R. : Prinzipien der Okklusion. Inf. Orthod. Kieferorthop.,14 : 171-212, 1982.

3) Kulmer, S., Ruzicka, B., Niederwanger, A., Moschen, I .: Incline and length of guiding elements in untreated naturally grown dentition. J. Oral Rehabil., 26 : 650-660, 1999.

4) 佐藤貞雄, 井坂文隆, 木村 智, 渡辺 享, 村居聖子, 秋本 進 : 日本人の咬合様式に関する研究 第 1 報 日本人正常咬合者 の歯の形態と誘導路. 顎咬合誌, 17 (2) ：89-96, 1996.

5) Celar, A., Sato, S., Akimoto, S., Yamamura, S., Masumoto, A., Slavicek, R. : Sequential Guidance with Canine Dominance in Japanese and Caucasian Samples. Bull. Kanagawa Dent. Col., 122 : 18-24, 1994.

6) Celar, G.A., Kubota, M., Akimoto, S., Sato, S., Slavicek, R., Hennerbichler, E. : Inclines of occlusal guidance, wear facets, and hinge axis path considering sequential guidance with canine dominance. Bull. Kanagawa Dent. Col., 25 : 3-9, 1997.

7) Piehslinger, E., Celar, G.A., Celar, M.R, Slavicek, R. : Computerized axiography: Principles and methods. J. Craniomand. Practice, 9 : 344-355, 1991.

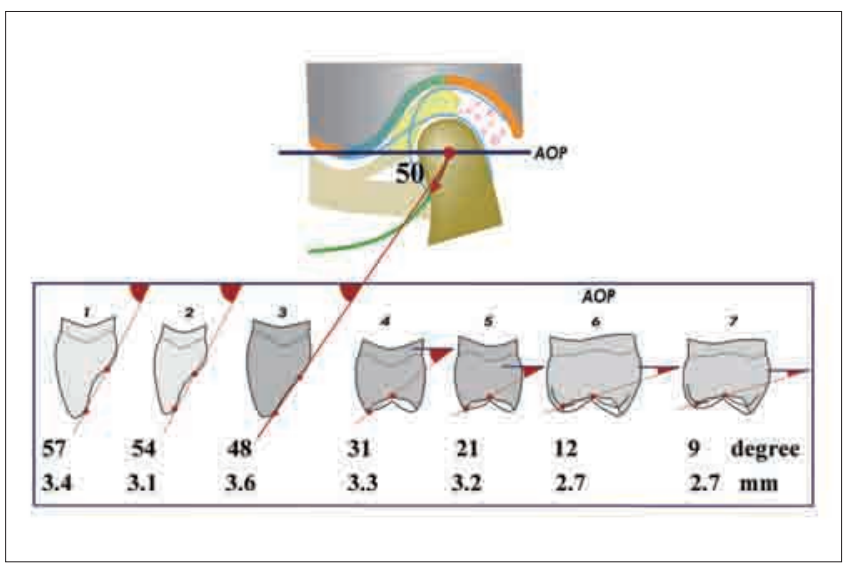

図 10 咬合誘導路と矢状顆路傾斜角 (SCl). 日本人の平均的咬合 誘導路の傾斜角は前歯から兒歯部まで順次性を示した．これは犬歯 主導の順次誘導咬合の概念と一致するものであった. 犬歯の咬合誘 導路角（48 度）と矢状顆路傾斜角（50 度）とはきわめて近似する 傾斜であった。

導順次誘導咬合を維持するものと考えられた. pOPは, 加 齢にともなって徐々に平坦化した。この変化はRCIを増加 させ，臼歯離開をより容易にしている。しかし，アングル II級における pOP はアングル I 級および吕級と比べ急峻 となっており, 後方歯において干渉を生じる危険性が増大 することが示唆された。

\section{謝辞}

本研究は, 神奈川歯科大学咬合医学研究所において文部 科学省オープンリサーチ研究開発拠点整備事業の研究費で 行われた。

8) Precious, D., Delaire, J. : Balanced facial growth: a schematic interpretation. O.S.O.M.O.P., $63: 637-644,1987$.

9）佐藤貞雄 : 不正咬合治療へのアプローチ。19-22, 東京臨床 出版（東京）, 1991.

10）佐藤貞雄, 本柳和子, 鈴木孝雄, 今坂祥子, 鈴木祥井 : 顎骨格 形態の経年的変化と不正咬合発現との関連についての一考 察. 日矯歯誌, 47 : 186-196, 1988.

11) Sato, S., Suzuki, N., Suzuki, Y. : Longitudinal study of the cant of the occlusal plane and the denture frame in case with congenitally missing third molars. J. Jpn. Ortho. Soc., 47 : 517 525,1988 .

12) Sato, S. : Alteration of Occlusal Plane due to Posterior Discrepancy Related to Development of Malocclusion : Introduction to Denture Frame Analysis. Bull. Kanagawa Dent. Col., 15: 115-123, 1987.

13) Sato, S., Suzuki, Y. : Relationship between the development of skeletal mesio-occlusion and posterior tooth-to-denture base discrepancy. J. Jpn. Ortho. Soc., 47 : 796-810, 1988.

14) McHorris, W.H. : Focus on anterior guidance. J. Gnathology, 8 : 3-13, 1989. 